\title{
STILISTIKA MORFOLOGI DALAM AYAT-AYAT PENCIPTAAN MANUSIA
}

\author{
Nur Amalia Sholihah \\ SDIT Umar Harun \\ amaliamahmudy@gmail.com
}

\begin{abstract}
This paper examines the language style contained in the verses of the human creation process. The problems studied include the stylistics of the Qur'an from the aspect of morphology and its implications for the meaning contained therein. The choice of words and the structure of the sentence form in this discussion looks unique, because they have different editors in each mention. This research is part of library research. The steps taken in this research are: a) Collecting verses about the human creation process; (b) identifying the verse of the human creation process by considering two things, the first, that the words have a set of morphological meanings. The second, that these morphological meanings are presented through various constructions; (c) listing the results of identification; (d) analyzing the relationship between the construction of the verses of the human creation process with each other, both in terms of conformity and contradiction; (e) describing the analysis results and concluding. The results of this study indicate that the morphological aspects contained in the verse in the process of human creation show the miraculous side of the Qur'an. The difference in the editorial of the al-Qur'an does not lead to deviations from the meaning to be conveyed. In fact, this has the effect of meaning which explains and strengthens one another.
\end{abstract}

Keywords: Stylistics, Morphology, I'jaz al-Qur'an, Implications.

\begin{abstract}
Abstrak
Tulisan ini mengkaji tentang gaya bahasa yang terdapat dalam ayat-ayat proses penciptaan manusia. Masalah yang dikaji mencakup stilistika al-Qur`an dari aspek morfologi dan implikasinya terhadap makna yang terkandung di dalamnya. Pilihan kata dan struktur bentuk kalimat pada pembahasan ini terlihat unik, karena mempunyai perbedaan redaksi dalam setiap penyebutannya. Penelitian ini bagian dari penelitian kepustakaan (library research). Langkah-langkah yang dilakukan dalam penelitian ini adalah: (a) Mengumpulkan ayat-ayat tentang proses penciptaan manusia. (b) Mengidentifikasi ayat proses penciptaan manusia dengan mempertimbangkan dua hal, yaitu pertama, bahwa kata-kata itu memiliki sekumpulan makna morfologis. Kedua, bahwa makna-makna morfologis tersebut disajikan melalui konstruksi yang beragam. (c) Membuat daftar hasil identifikasi. (d) Menganalisa hubungan konstruksi ayat-ayat proses penciptaan manusia satu sama lain, baik hubungan persesuaian maupun pertentangan. (e) Mendeskripsikan hasil analisa dan menyimpulkan. Hasil penelitian ini menunjukkan bahwa aspek morfologi yang terdapat dalam ayat proses penciptaan manusia menunjukkan sisi kemu'jizatan al-Qur`an. Perbedaan redaksi al-Qur`an tidak membawa penyimpangan terhadap makna yang ingin
\end{abstract}




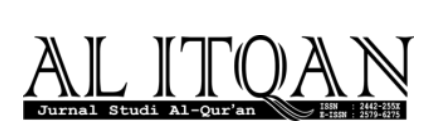

Stilistika Morfologi dalam Ayat-Ayat Penciptaan Manusia

Nur Amalina Sholihah

Doi: doi.org/10.47454/itqan.v3i2.25

disampaikan. Justru hal ini membawa pengaruh pemaknaan yang saling menjelaskan dan menguatkan antara satu dengan lainnya.

Kata Kunci: Stilistika, Morfologi, I'jaz al-Qur'an, Implikasi

\section{A. Pendahuluan}

Kemu'jizatan al-Qur`an terdapat di semua kandungan lafal dan maknanya. ${ }^{1}$ Dalam penyampaian pesan-pesannya, al-Qur`an menggunakan gaya bahasa yang memukau dengan style yang bervariasi. Selain itu, tingginya kualitas bahasa al-Qur`an dan luasnya makna yang terkandung juga dibuktikan dengan adanya beragam pendekatan dan metode yang dipakaiuntuk memahaminya.

Gaya bahasa merupakan aspek yang menempati posisi penting dalam ruang lingkup stilistika. ${ }^{2}$ Bahasan-bahasan dalam ilmu stilistika ini banyak diserap dan dikembangkan dari ilmu retorika yang sudah berkembang sejak zaman Yunani Kuno. Kelahiran stilistika sebagai sebuah disiplin ilmu sering dinisbatkan kepada Charles Bally hingga akhirnya stilistika mengalami perkembangan. Stilistika mengakaji seluruh fenomena bahasa mulai dari aspek fonologi, morfologi, sintaksis, semantik, dan imageri. ${ }^{3}$ Oleh karena itu, dengan kata lain stilistika juga dapat dikatakan sebagai salah satu alat yang dapat digunakan untuk menguak aspek-aspek keindahan teks dengan berusaha memahami kandungan teks dan menganalisis unsur-unsur pembentuk teks. ${ }^{4}$

A. Hanafi sebagaiamana dikutip oleh Qalyubi menjelaskan bahwa di dalam al-Qur’an banyak dimuat kisah-kisah masa lalu, yakni terdapat dalam 35 surat dan 1600 ayat. ${ }^{5}$ Kisahkisah yang ada dalam al-Qur’an disampaikan dengan gaya bahasa dan redaksi yang variatif dan berulang-ulang. Tidak hanya disampaikan satu atau dua kali dalam surah yang sama, terkadang juga kembali disampaikan di dalam surah yang berbeda. Perintah ataupun ajaran moral disampaikan secara tidak langsung kepada manusia sebagai penikmat sekaligus sasaran kisah. Berkaitan dengan ini, tulisan mencoba untuk mengkaji pengulangan lafal dan gaya bahasa yang termuat dalam ayat-ayat proses penciptaan manusia. Sebelumnya, jika dibandingkan dengan kisah Nabi Yūsuf, ayat tentang proses penciptaan manusia ini

\footnotetext{
${ }^{1}$ Manna’ al-Qaț̣an, Mabāhith fi 'ulūm al-Qur ‘ān, terj. Umar Mujtahid (Jakarta: Ummul Qurra', 2016), hlm. 416. ${ }^{2}$ Mursalim, "Gaya Bahasa Pengulangan Kisah Nabi Musa as dalam Al-Qur'an: Suatu Kajian Stilistika”, Lentera, Vol. 1, No. 1(2017), hlm. 3.

${ }^{3}$ Syihabuddin Qalyubi, Ilm Al-Uslūb: Stilistika Bahasa dan Sastra Arab(Yogyakarta: Karya Media, 2013), hlm. 70.

${ }^{4}$ Syihabuddin Qalyubi, Stilistika Al-Qur`an:Makna di Balik Kisah Ibrahim(Yogyakarta: LKIS, 2008), hlm. 20. ${ }^{5}$ Ibid, hlm. 1.
} 
Stilistika Morfologi dalam Ayat-Ayat Penciptaan Manusia Nur Amalina Sholihah

Doi: Doi: doi.org/10.47454/itqan.v3i2.25

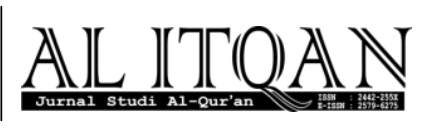

disampaikan dengan bentuk yang berbeda. Kisah Nabi Yūsuf hanya dijelaskan dalam satu surah saja, yaitu surah Yūsuf. Sedangkan kisah dan peristiwa proses penciptaan manusia dimuat dalam al-Qur`an secara terpisah-pisah. Dalam penyampaiannya pun menggunakan redaksi yang variatif. Seperti di sebutkan dalam firman Allah Subhānahu wa Ta'àlā surat alHajj ayat 5 dan surat al-Mu'minūn ayat 12-14.

Penyampaian peristiwa tentang proses penciptaan manusia pada ayat-ayat di atas memiliki kata dan struktur bentuk kalimat yang unik. Tekstual unik dalam hal ini dapat dilihat dari redaksinya yang menggunakan repetisi tertentu, meliputi pemilihan kata dan pengulangan kata dengan bentuk yang sama, yaitu nutfah, 'alaqah, dan mudghah. Adanya pemilihan kata dan pengulangan kata di sini jika dilihat dari sisi makna dan struktur kalimatnya tentu akan mempunyai kandungan isi dan hikmah yang berbeda.

Pemilihan ayat-ayat proses penciptaan manusia sebagai objek kajian dalam penelitian ini juga didasari oleh beberapa faktor, di antaranya: pertama ayat-ayat tentang proses penciptaan manusia kurang lebih tersebar dalam 22 surah atau sekitar 19,3\% dari jumlah keseluruhan surah di dalam al-Qur’an. Persebaran yang cukup merata. Kedua penyebutan ayat-ayat proses penciptaan manusia yang konsisten, maksudnya ayat-ayat tersebut sering kali disampaikan setelah ayat-ayat yang menyatakan balasan orang-orang yang berdusta dan beriman, serta disampaikan sebelum ayat-ayat yang menyatakan akan kebesaran Allah Subhānahu wa Ta’ālā.

\section{B. Konsep Stilistika Morfologi Syahabuddin Qalyubi}

Berbicara tentang al-Qur`an dari sudut stilistika, tidak dapat dilepaskan dari konsep i’jaz al-Qur 'ān, karena stilistika al-Qur`an merupakan ilmu yang mengkaji bahasa al-Qur`an. Pemilihan huruf dan penggabungan antar konsonan dengan vokal. Dalam hal ini, 'al-Jurjāni mengatakan bahwa sesungguhnya mukjizat al-Qur`an hanya terdapat pada struktur al-Qur`an itu sendiri, bukan di luarnya. ${ }^{6}$

Mujahid mengatakan telaah ihwal data dan makna telah menjadi perhatian para ulama jauh sebelum para ahli linguistik Barat memulainya. Para ahli yang membahas masalah itu dapat dibagi menjadi tiga kelompok, yaitu ahli ușūl fiqh, para sastrawan, dan ahli bahasa. Ahli bahasa memandang bahasa sebagai gudang perbendaharaan yang perlu diungkapkan isinya,

\footnotetext{
${ }^{6}$ Akhmad Muzakki, Stilistika al-Qur`an: Memahami Karakteristik Bahasa Ayat-Ayat Eskatologi (Malang: 2015, UIN-Maliki Press), hlm. 49.
} 
karena itu telaah mereka terhadap hubungan antara kata dan makna meliputi berbagai aspek, di antaranya tentang etimologi, sinonim, homonim, polisemi, antonim, makna denotatif dan konotatif, perubahan makna dan pengembangan kata. ${ }^{7}$

Secara umum tujuan utama yang ingin dicapai dalam memahami bahasa adalah memahami makna. Pembaca atau pendengar perlu melakukan analisis struktur, leksikal, dan kontekstual untuk mencapai makna tersebut. Dalam hal ini analisis struktur dibagi dua, yaitu sintaksis dan morfologi. Matthew dalam buku Morphology: an Introduction to the Theory of Word-Structure (1974) membagi morfologi menjadi dua bidang, yaitu morfologi infleksional (inflectional morphology) dan morfologi leksikal (lexical morphology). Morfologi leksikal mengkaji kaidah-kaidah pembentukan kata yang menghasilkan kata-kata baru, yang secara leksikal berbeda (beridentitas baru) dari kata yang menjadi dasarnya. Hal ini berbeda dengan morfologi infleksional yang mengkaji hasil-hasil pembentukan kata yang berasal dari leksem yang sama. Pemilahan seperti itu akan membawa konsekuensi bahwa pembahasan utamanya adalah masalah derivasi dan infleksi. Derivasi adalah proses pembentukan kata yang menghasilkan leksem baru (menghasilkan kata-kata yang berbeda dari paradigma yang berbeda), sedangkan infleksi adalah pembentukan kata yang menghasilkan kata-kata yang berbeda dengan paradigma yang sama. Pembentukan derivasi bersifat tidak dapat diramalkan, sedangkan pembentukan infleksi bersifat teramalkan ${ }^{8}$.

Menurut Syihabuddin Qalyubi, analisis 'ilm al-uslūb dari aspek al-Mustawā al-șarfi (ranah morfologi) sangat luas cakupannya. Namun, paling tidak mencakup dua aspek, yaitu ikhtiyar al-șighah (pemilihan bentuk kata) dan al- 'udūl bi al-șighhah 'an al-Aṣl al-Siyāqi, yaitu berpindah satu bentuk kata ke bentuk kata lainnya dalam konteks yang sama. Analisis stilistika berusaha untuk mengungkap mengapa terjadi perubahan bentuk kata pada ayat yang sama dan apa pengaruhnya terhadap pemaknaan. ${ }^{9}$

Pemilihan kata yang menjadi ranah kajian stilistika terbagi dalam dua kelompok, yaitu pertama pilihan kata yang erat kaitannya dengan makna dan kedua pilihan kata yang erat kaitannya dengan posisinya dalam struktur kalimat. Bagian pertama dikaji dalam ruang lingkup leksikal, sedangkan bagian kedua dikaji dalam ranah gramatika. ${ }^{10}$

\footnotetext{
${ }^{7}$ M. Aunul Hakim “Stilistika Morfologi Al-Quran Juz 30”, Lingua, Vol. 5, No. 1, (2010), hlm. 18.

${ }^{8}$ Dwi Purnanto, "Kajian Morfologi Derivasional dan Infleksional dalam Bahasa Indonesia", Kajian Linguistik dan Sastra, 18, (2006) hlm. 138.

${ }^{9}$ Qalyubi, 'Ilm al-Uslūb, hlm. 81.

${ }^{10}$ Qalyubi, Stilistika al-Qur`an, hlm. 34.
} 
Stilistika Morfologi dalam Ayat-Ayat Penciptaan Manusia Nur Amalina Sholihah

Doi: Doi: doi.org/10.47454/itqan.v3i2.25

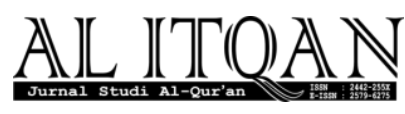

Penggunaan pilihan kata yang erat kaitannya dengan posisinya dalam struktur kalimat (gramatika) itu tergantung pada tujuan yang hendak dicapai. Salah satu tujuan dari studi gramatika adalah untuk mendeteksi dan menganalisa kata atau kalimat yang ambigu. Adanya tujuan ini mempunyai keterkaitan dengan disiplin ilmu stilistika yang menggunakan gramatika sebagai salah satu pendekatannya, sehingga hal ini dapat memperjelas pilihan dalam sebuah bahasa. ${ }^{11}$

Sebagaimana disebutkan di atas, bahwa bahasan stilistika berkisar pada alasan pemilihan kata atau efek pemilihan yang dilakukan pembuat teks. Pada kesempatan ini, objek studi dalam penelitian ini adalah pemilihan Allah Subhānahu wa Ta'ālā terhadap bentukbentuk kata atau kalimat yang terdapat dalam ayat-ayat proses penciptaan manusia. Pemilihan terhadap suatu bentuk kata atau kalimat pasti terdapat pengaruh terhadap makna atau keindahan tuturan al-Qur`an. Pilihan-pilihan tersebut banyak sekali, antara lain aspek kata kerja, aspek kata benda, aspek kalimat nominal, dan aspek kalimat verbal.

Qalyubi mengutip ungkapan dari al-`Awwā bahwa ada tiga konteks yang dapat membantu memahami makna kata dalam al-Qur`an. Ketiga konsep tersebut adalah, pertama konteks umum, mencakup ajaran-ajaran Islam secara umum, teks al-Qur`an, penjelasannya yang terdapat dalam sunnah (qauliyyah dan `amaliyyah), serta pendapat para sahabat. Kedua, konteks tema, yakni konteks dari ayat yang memuat kata tersebut. Untuk memahami konteks tema secara menyeluruh, nuansa yang mempengaruhi pemilihan kata harus diperhatikan. Ketiga, konteks bahasa, ini mencakup kata-kata dan struktur kalimat yang mewadahi kata yang diteliti. ${ }^{12}$

Morfologi termasuk salah satu studi kebahasaan (linguistik) yang mengkaji kata atau leksikon ${ }^{13}$ suatu bahasa. Kata dalam hal ini dipandang sebagai satuan padu bentuk dan makna yang memperlihatkan aspek valensi sintaksis, yakni kemungkinan-kemungkinan yang dimiliki kata untuk berkombinasi dengan kata lain dalam kelompok. Menurut tradisi, studi morfologi akan mengkaji struktur internal kata dalam kaitannya dengan kata lain dalam suatu paradigma. Sedangkan sintaksis berkaitan dengan fungsi-fungsi eksternal kata dan kaitannya dengan kata lain dalam kalimat.

\footnotetext{
${ }^{11}$ Ibid. , hlm. 66.

${ }^{12}$ Qalyubi, stilistika al-Qur`an, hlm. 35.

${ }^{13}$ Komponen bahasa yang memuat semua informasi tentang makna dan pemakaian kata dalam bahasa.
} 
Pada aspek analisis morfologi ini, mengulas hakikat kalimat di luar susunannya, yakni mengenai struktur pembentukan kalimat, perubahan kalimat baik pengurangan maupun penambahan, atau pengaruhnya pada makna. Kemudian, pada analisis ini, juga membahas perubahan mendasar pada kalimat tertentu dari aspek bahasa maupun lahjah yang digunakan, dengan tujuan agar sampai ada uslūb masing-masing bahasa dari sisi pembentukan kalimat. ${ }^{14}$

Dalam analisis morfologi, perlu dipahami tiga hal. Pertama, bahwa kata-kata itu memiliki sekumpulan makna morfologis, seperti nominal, verbal, ajektival, preposisional. Kedua, bahwa makna-makna morfologis tersebut disajikan melalui struktur yang beragam. Struktur ini terdiri atas kata dasar (mujarrad), kata yang telah mengalami afiksasi (mazid), dan kata dengan morfem zero. Ketiga, struktur-struktur itu berhubungan satu sama lain, baik hubungan persesuaian maupun pertentangan. ${ }^{15}$

Pada tingkat gramatika, kata secara tradisional akan dipahami sebagai unsur terkecil bahasa yang akan diidentifikasikan tentang asal dan bentuknya dalam kerangka berpikir. Setiap bahasa tentunya dapat dijabarkan ihwal kata itu dan properti-properti morfosintaksisnya. ${ }^{16}$

\section{Al-Qur`an dan Konsep Proses Penciptaan Manusia}

Pada abad ke-19, dunia ilmu pengetahuan riuh dengan temuan baru yang dianggap kontroversial, yaitu teori evolusi. Teori ini hingga beberapa waktu yang lalu masih menjadi bahan perdebatan para ilmuwan. Hingga tahun 2008, hanya satu nama yang diakui sebagai pencetus teori evolusi, yaitu Charles Robert Darwin (1809-1882). ${ }^{17}$ Dalam teorinya ini, ia menyatakan bahwa mahluk hidup selalu menyesuaikan diri dengan lingkungan alamiahnya yang terus berubah. Mahluk yang paling dapat menyesuaikan diri itulah yang akan survive dan berkembang menjadi mahluk yang lebih kompleks atau lebih tinggi tingkatannya, begitu sebaliknya. Jadi, menurut teori evolusi, mahluk berevolusi dari jenis organisme yang paling sederhana (mikroba uniseluler) hingga mahluk yang kompleks (multiseluler) dalam kurun waktu ratusan juta tahun.

Pengetahuan tentang evolusi yang seringkali bertolak belakang dengan persepsi umum di masyarakat, menyatakan bahwa manusia tercipta dari proses reproduksibiologis.

\footnotetext{
${ }^{14}$ Muhammad Daud, al- 'Arabiyah wa 'Ilm al-Lughah al-Hadis (Kairo: Dār al-Gharīb, 2001), hlm. 106.

${ }^{15}$ M. Aunul Hakim “Stilistika Morfologi Al-Quran Juz 30”, Lingua, Vol. 5, No. 1 (2010), hlm. 19.

${ }^{16}$ Dwi Purnanto, "Kajian Morfologi Derivasional dan Infleksional", hlm. 136.

${ }^{17}$ Lajnah Pentashihan Mushaf al-Qur`an, Penciptaan Manusia: Dalam Perspektif al-Qur`an dan Sains, (Jakarta: Lajnah Pentashihan Mushaf al-Qur`an, 2010), hlm. 8.
} 
Stilistika Morfologi dalam Ayat-Ayat Penciptaan Manusia Nur Amalina Sholihah

Doi: Doi: doi.org/10.47454/itqan.v3i2.25

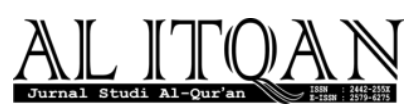

Bersamaan dengan berkembangnya ilmu pengetahuan yang semakin berkembang, teori tentang proses reproduksi manusia ditemukan. Pada masa Plato dan Aristoteles, banyak prokontra tentang teori terciptanya embrio. Teori pertama percaya bahwa embrio ${ }^{18}$ manusia berbentuk manusia mikro dan tertanam di dalam sperma laki-laki. Teori kedua juga tidak ada bedanya dengan yang pertama, kecuali bahwa embrio yang berbentuk manusia mini itu tertanam dalam rahim perempuan dan terbentuk dari sel telur. ${ }^{19}$

Teori yang baru terungkap oleh ilmu pengetahuan abad 20 ini, sebenarnya sudah diuraikan dalam berbagai surah al-Qur`an yang diturunkan ratusan tahun sebelumnya. Ayat ke-2 surah al-insān mengindikasikan adanya campuran antara unsur yang datang dari laki-laki dan perempuan dalam pembentukan embrio. Allah Subhāanahu wa Ta'ālā berfirman:

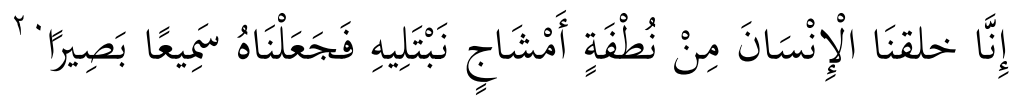

Sesungguhnya Kami telah menciptakan manusia dari setetes mani yang bercampur yang Kami hendak mengujinya (dengan perintah dan larangan), karena itu Kami jadikan Dia mendengar dan melihat.

Kata "setetes mani" pada ayat ini adalah terjemahan dari bahasa Arab nutfatin amshāj yang artinya bercampur, yakni bercampurnya air yang berasal dari laki-laki dan permpuan. Hal ini dinyatakan oleh Nabi Muhammad Salla Allah 'Alaihy wa Sallam saat menjawab pertanyaan seorang Yahudi.

Sejarah seluruh kehidupan manusia, mulai dari sperma dan indung telur hingga penyakit pikun yang melanda para lanjut usia, tertuang lengkap dalam surah al-Mu'minūn ayat 13-14.

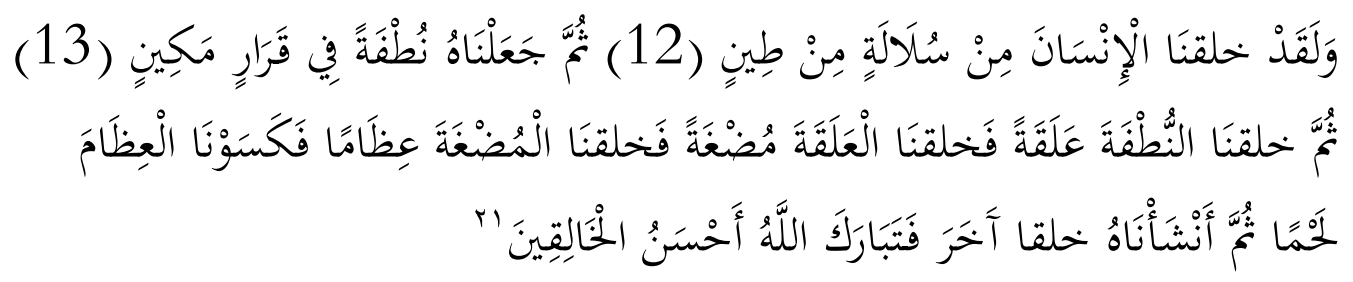

13. Kemudian Kami menjadikannya air mani (yang disimpan) dalam tempat yang kokoh (rahim). 14. Kemudian, air mani itu Kami jadikan sesuatu yang melekat, lalu sesuatu yang melekat itu Kami jadikan segumpal daging, dan segumpal daging itu

\footnotetext{
${ }^{18}$ Embrio adalah jasad hidup yang masih dalam perkembangan (pertumbuhan) awal, belum mempunyai bentuk yang jelas. Lihat dalam Timpenyusun Kamus Pusat Bahasa, Kamus Bahasa Indonesia (Jakarta: Departemen Pendidikan Nasional, 2008), hlm. 386.

${ }^{19}$ Lajnah Pentashihan Mushaf al-Qur`an, Penciptaan Manusia: Dalam Perspektif al-Qur`an dan Sains, hlm. 78.

${ }^{20}$ al-Qur`an, 76: 2.

${ }^{21}$ al-Qur`an, 23: 12-14
} 
Kami jadikan tulang belulang, lalu tulang belulang itu Kami bungkus dengan daging. Kemudian, Kami menjadikannya mahluk yang (berbentuk) lain. Mahasuci Allah, Pencipta yang paling baik.

Dan pada surah al-Hajj ayat 5 dijelaskan rincian proses perkembangan embrio dan janin.

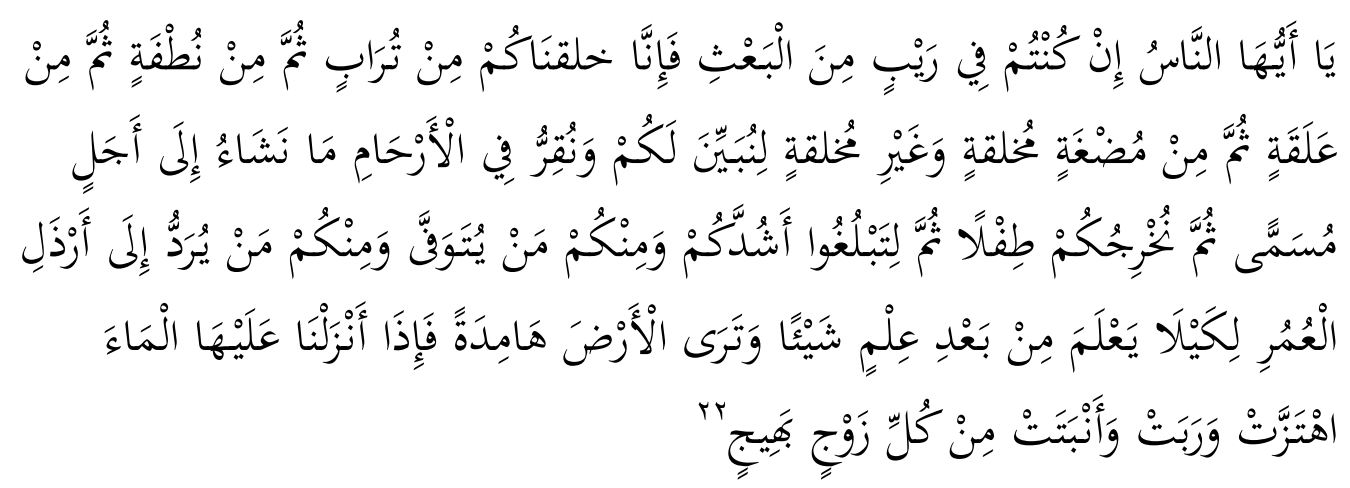

Wahai manusia! Jika kamu meragukan (hari) kebangkitan, maka sesungguhnya Kami telah menjadikan kamu dari tanah, kemudian dari setetes mani, kemudian dari segumpal darah, kemudian dari segumpal daging yang sempurna kejadiannya dan yang tidak sempurna, agar Kami jelaskan kepada kamu; dan Kami tetapkan dalam rahim menurut kehendak Kami sampai waktu yang sudah ditentukan, kemudian Kami keluarkan kamu sebagai bayi, kemudian (dengan berangsur-angsur) kamu sampai kepada usia dewasa, dan di antara kamu ada yang diwafatkan dan (ada pula) di antara kamu yang dikembalikan sampai usia sangat tua (pikun), sehingga dia tidak mengetahui lagi sesuatu yang telah diketahuinya. Dan kamu lihat bumi ini kering, kemudian apabila telah Kami turunkan air (hujan) di atasnya, hiduplah bumi itu dan menjadi subur dan menumbuhkan berbagai jenis pasangan (tetumbuhan) yang indah.

Dari ayat ini diketahui bahwa perkembangan embrio terjadi secara bertahap. Tahapantahapan yang digambarkan dua ayat ini sama persis dengan temuan ilmu pengetahuan modern, yakni embrio yang telah dibuahi akan berkembang sekitar 3 bulan. Setelah itu, terjadi perkembangan janin selama kurang lebih 6 bulan. ${ }^{23}$

Pada pembahasan proses penciptaan manusia ini, akan di sebutkan pula tahap-tahap perkembangan embrio bersamaan dengan bahasan tentang ayat-ayat al-Qur`an yang berkaitan dengan setiap tahapannya. Dalam beberapa ayat al-Qur`an, perkembangan manusia dijelaskan dengan redaksi umum dan ada dengan redaksi yang lebih rinci.

Berdasarkan keterangan singkat di atas, diketahui setidaknya ada tiga rincian perkembangan manusia yang diuraikan oleh al-Qur`an yang kemudian dikonfirmasi oleh

\footnotetext{
22 al-Qur`an, 22: 5

${ }^{23}$ Lajnah Pentashihan Mushaf al-Qur`an, Penciptaan Manusia: Dalam Perspektif al-Qur`an dan Sains, hlm. 80.
} 
Stilistika Morfologi dalam Ayat-Ayat Penciptaan Manusia Nur Amalina Sholihah

Doi: Doi: doi.org/10.47454/itqan.v3i2.25

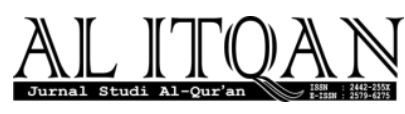

temuan-temuan ilmu pengetahuan, yaitu sperma dan sel telur, rahim, pembentukan 'alaqah ${ }^{24}$, pembentukan mudghah ${ }^{25}$, pembentukan otot, perkembangan janin, dan perkembangan metafisik.

Ketika saripati $^{26}$ tanah masuk ke dalam tubuh manusia, saripati itu lantas dipakai oleh tubuh sebagai starting materials dalam proses metabolisme pembentukan nutfah di dalam selsel reproduksi. Kata nutfah seringkali diterjemakan dengan air mani atau setetes mani. Kata yang biasa digunakan ampir serupa dengan nutfah adalah nutfatin amsyāj, atau setetes mani yang bercampur. Hal ini mengandung arti percampuran dua nutfah atau benih, yaitu dari lakilaki (sperma) dan perempuan (sel telur, ovarium). Nutfah juga disebut sebagai air yang hina (māim mahīn, surah al-Mursalat: 20) atau air yang terpancar (māim dāfiq, surah al-Țāriq). Istilah yang pertama, merujuk pada tempat keluarnya air itu, sebagai tempat yang hina, alat genitalia, suatu organ yang juga berfungsi untuk membuang urine. Sedangkan istilah yang kedua menunjukkan proses masuknya sprema ke dalam rahim. ${ }^{27}$

Air mani atau nutfah dalam tahapan-tahapan perkembangan manusia, disebutkan dalam ayat berikut: al-Mu'minūn: 13 .

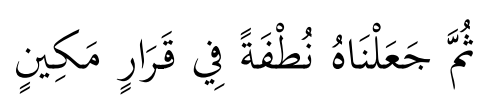

Rahim adalah tempat bagi embrio dan janin untuk tumbuh dan berkembang. Rahim oleh al-Qur`an disebut sebagai tempat yang aman. Beberapa hal yang menjadi alasan mengapa rahim layak disebut sebagai tempat yang aman, yaitu terdapat

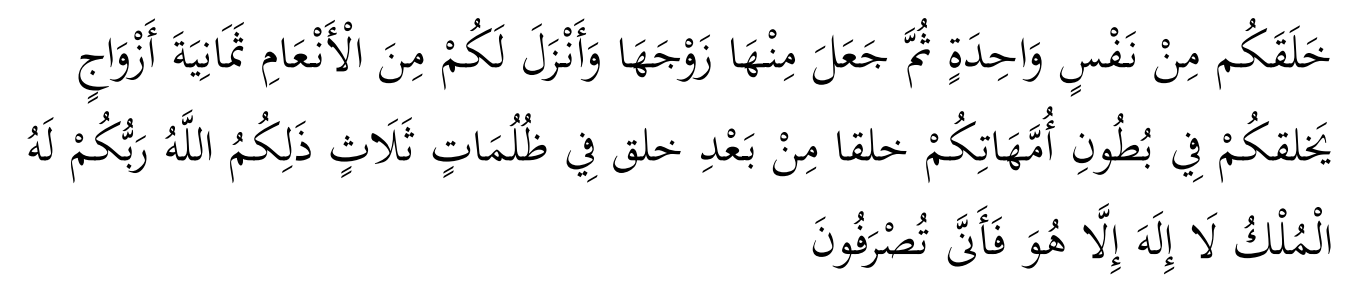

Dia menciptakan kamu dari seorang diri kemudian Dia jadikan daripadanya isterinya dan Dia menurunkan untuk kamu delapan ekor yang berpasangan dari binatang ternak. Dia menjadikan kamu dalam perut ibumu kejadian demi kejadian dalam tiga kegelapan. Yang (berbuat) demikian itu adalah Allah, Tuhan kamu, Tuhan yang mempunyai kerajaan. tidak ada Tuhan selain dia; Maka bagaimana kamu dapat dipalingkan? ${ }^{28}$

\footnotetext{
24 'Alaqah diartikan sebagai darah yang beku, Lihat di Musțafa al-Maraghi, Tafsir al-Maraghi, terj. Bahrun Abubakar, Hery Noer Aly, Anshori Umar, Vol. 18, hlm. 11.

${ }^{25}$ Mudghah diartikan sebagai sepotong daging yang bisa dikunyah.

${ }^{26}$ Saripati dalam KBBI diartikan sebagai inti atau pokok yang terpenting dari sesuatu

${ }^{27}$ Lajnah Pentashihan Mushaf al-Qur`an, Penciptaan Manusia: Dalam Perspektif al-Qur`an dan Sains, hlm. 81.

${ }^{28}$ al-Qur’an, 39: 6.
} 
Dari ayat di atas, beberapa peneliti kemudian menafsirkan kata "tiga kegelapan" itu dengan tiga lapisan membran amniotik yang mengelilingi rahim, dinding rahim, dan dinding abdomen di bagian perut, yaitu ${ }^{29}$ lapisan membran amnion yang mengandung cairan yang memungkinkan janin untuk berenang. Kondisi ini melindungi janin dari benturan bendabenda luar, lapisan membran chorion,lapisan membran decidua.

Pembentukan 'alaqah yang terjadi di dalam rahim ibu merupakan bentuk praembrionik yang terjadi setelah percampuran sperma dan ovarium. Alaqah terbentuk sekitar 24-25 hari.

Tahap kedua dari pertumbuhan embrio ditandai dengan berubahnya bentukan seperti lintah menjadi mudghah, sesuatu yang mirip dengan sepotong daging atau permen karet yang telah dikunyah. Pembentukan mudghah ini juga disebutkan dalam surah al-Mu'minūn ayat 14:

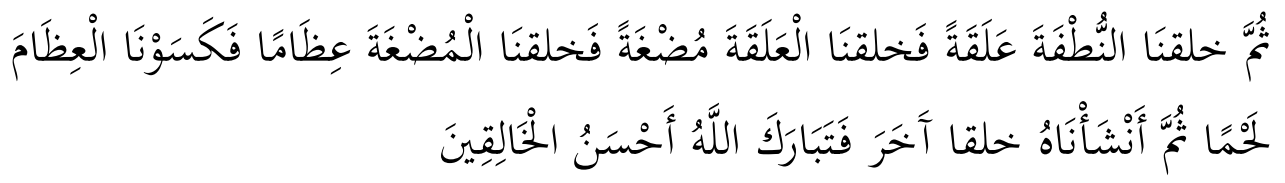

Kemudian air mani itu Kami jadikan segumpal darah, lalu segumpal darah itu Kami jadikan segumpal daging, dan segumpal daging itu Kami jadikan tulang belulang, lalu tulang belulang itu Kami bungkus dengan daging. Kemudian Kami jadikan Dia mahluk yang (berbentuk) lain. Maka Maha sucilah Allah, Pencipta yang paling baik.

\section{Ayat Proses Penciptaan Manusia dalam Kacamata Stilistika Morfologi}

Syihabudin Qalyubi mengutip ungkapan dari Count de Buffon yang menyatakan bahwa gaya adalah manusia itu sendiri (le style est i'homme meme). ${ }^{30}$ Setiap manusia atau pencipta suatu karya memiliki gayanya sendiri. Bahkan, setiap diri manusia mempunyai gaya tuturan yang berbeda-beda yang terkadang disesuaikan pada situasi atau konteks yang dihadapinya. Dalam tuturannya pun terkadang ia akan menggunakan gaya yang khas dan cocok dengan konteks.Demikian pula dalam al-Qur`an, Allah Subḥ̄anahu wa Ta'ālā sebagai Maha Pencipta juga menggunakan gaya dalam mengungkapkan firman-Nya, dan gaya yang digunakan oleh Allah Subhānahu wa ta'àlà di sini tentu berbeda dengan gaya yang digunakan oleh manusia saat berkomunikasi atau menyampaikan pendapat. Penggunaan dan pilihan kata yang digunakan dalam al-Qur`an inilah yang nantinya akan dibahas dengan menggunakan konsep stilistika.

\footnotetext{
${ }^{29}$ Lajnah Pentashihan Mushaf al-Qur`an, Penciptaan Manusia: Dalam Perspektif al-Qur`an dan Sains, hlm. 84. ${ }^{30}$ Qalyubi, Stilistika al-Qur`an, hlm. 31.
} 
Stilistika Morfologi dalam Ayat-Ayat Penciptaan Manusia Nur Amalina Sholihah

Doi: Doi: doi.org/10.47454/itqan.v3i2.25

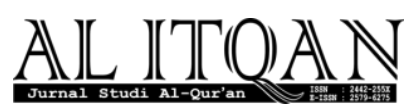

Setelah dilakukan identifikasi data stilistika dalam ayat al-Qur'an tentang proses penciptaan manusia dalam QS.al-Mu'minūn: 12-14, yaitu;

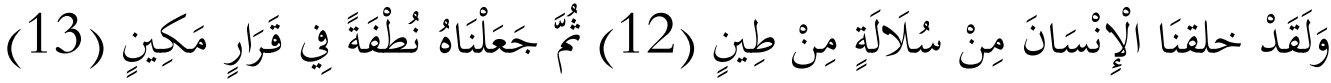

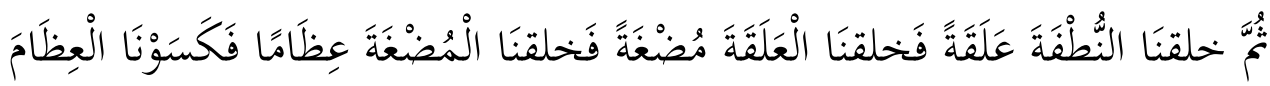

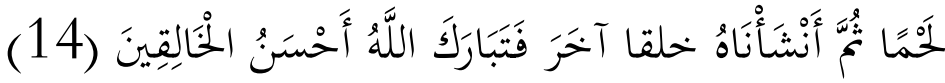

Dan Sesungguhnya Kami telah menciptakan manusia dari suatu saripati (berasal) dari tanah. Kemudian Kami jadikan saripati itu air mani (yang disimpan) dalam tempat yang kokoh (rahim). Kemudian air mani itu Kami jadikan segumpal darah, lalu segumpal darah itu Kami jadikan segumpal daging, dan segumpal daging itu Kami jadikan tulang belulang, lalu tulang belulang itu Kami bungkus dengan daging. kemudian Kami jadikan Dia mahluk yang (berbentuk) lain. Maka Maha sucilah Allah, Pencipta yang paling baik. ${ }^{31}$

Dan QS.al-Hajj: 5, yaitu;

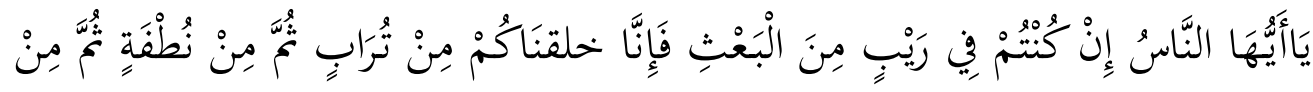

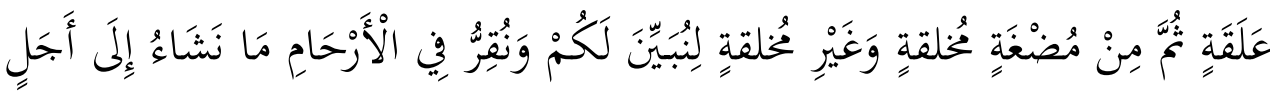

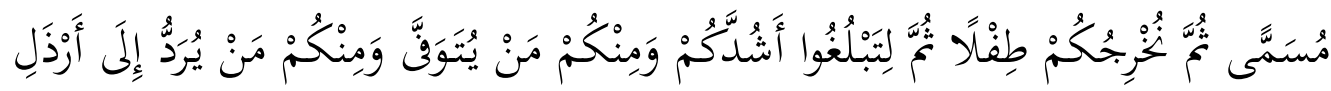

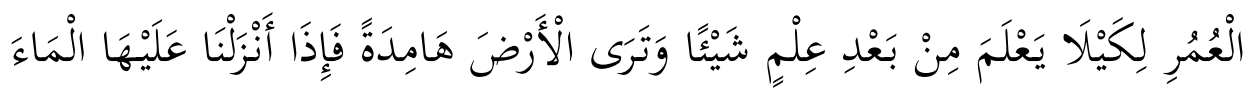

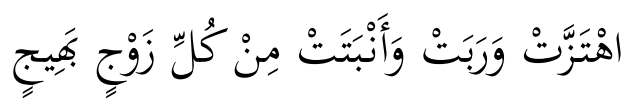

Hai manusia, jika kamu dalam keraguan tentang kebangkitan (dari kubur), Maka (ketahuilah) Sesungguhnya Kami telah menjadikan kamu dari tanah, kemudian dari setetes mani, kemudian dari segumpal darah, kemudian dari segumpal daging yang sempurna kejadiannya dan yang tidak sempurna, agar Kami jelaskan kepada kamu dan Kami tetapkan dalam rahim, apa yang Kami kehendaki sampai waktu yang sudah ditentukan, kemudian Kami keluarkan kamu sebagai bayi, kemudian (dengan berangsur- angsur) kamu sampailah kepada kedewasaan, dan di antara kamu ada yang diwafatkan dan (ada pula) di antara kamu yang dipanjangkan umurnya sampai pikun, supaya Dia tidak mengetahui lagi sesuatupun yang dahulunya telah diketahuinya. dan kamu Lihat bumi ini kering, kemudian apabila telah Kami turunkan air di atasnya, hiduplah bumi itu dan suburlah dan menumbuhkan berbagai macam tumbuhtumbuhan yang indah. ${ }^{32}$

Ditemukan bentuk-bentuk stilistika morfologi yang dapat diklasifikasikan sebagai berikut;

\section{Penggunaan fail isim damir}

\footnotetext{
${ }^{31}$ al-Qur`an, 23: 12-14.

${ }^{32}$ al-Qur`an, 22: 5.
} 
Dāmir atau kata ganti merupakan isim yang berfungsi untuk menggantikan atau mewakili penyebutan sesuatu atau seseorang maupun sekelompok benda atau orang. Dengan kata lain, d̦amir adalah setiap isim yang menunjukkan seseorang atau sesuatu yang ghāib dan hadir. ${ }^{33}$ Musțafa Ghulāyayni membagi dhamir (kata ganti) tersebut dalam

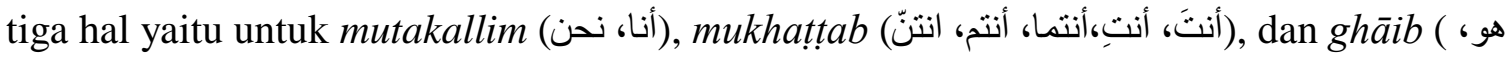

(هي، هما، هم، هنّ Masing-masing mempunyai perannya sendiri sesuai dengan kaidahkaidah Arab. ${ }^{34}$

al-Qur`an menggunakan berbagai macam bentuk kata ganti untuk menunjukkan makna Tuhan yang tunggal. Dalam QS.al-Hajj ayat 5 dan al-Mu'minūn ayat 12-14, Allah Subhạnahu wa Ta'ālā menggunakan kata ganti plural nā untuk menyebut diri-Nya. Kata

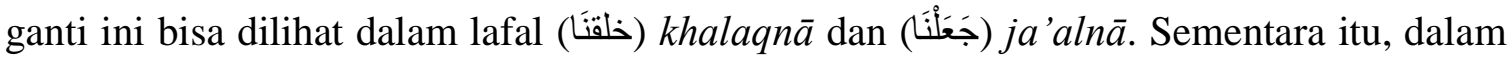
QS. lain, Allah Subhāanahu wa Ta'ālā menggunakan damīrmustatir,yang menempati

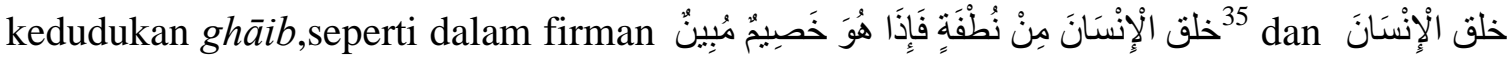

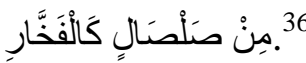

Dalam hal ini, Ibnu Kathīr ketika menjelaskan makna kata ganti plural yang dipakai untuk keperluan tunggal bagi seseorangmenjelaskan bahwa hal tersebut menunjukkan jenis penghambaan, dimana tatkala seseorang salat sendirian, maka kata ganti jamak tersebut mengingatkannya akan saudaranya yang juga diperintahkan Allah Subḥānahu wa Ta'ālā untuk beribadah sepertinya. ${ }^{37}$ Sementara jika Allah Subhānahu wa Ta'àlā menggunakan kata ganti plural dipakai untuk menunjukkan tunggal, maka hal ini berarti sifat ta'żim atau pengagungan Tuhan atas diri-Nya. ${ }^{38}$

Allah Subḥ̄nahu wa Ta'ālā tidak pernahmenyebutkan nama-Nya dengan șīghah tathniyah (bentuk dua).Sebab șighah tathniyahdalam pembahasan damīrmenunjukkan

\footnotetext{
${ }^{33}$ Saifudin Masykuri, Kajian dan Analisis Alfiyah, Vol. 1 (Kediri: Santri Salaf Press, 2016), hlm. 67.

${ }^{34}$ Mușțafa Ibn Muhammad Sālim Ghalāyaynī, Jāmi' al-Durūs al-'Arabiyyah (Beirut: al-Maktabah alAsh'ariyyah, 1993), hlm. 115.

${ }^{35}$ al-Qur'an, 16:4.

${ }^{36}$ al-Qur`an, 55:14.

${ }^{37}$ Abū al-Fidā' Ismā'il Ibn Umar Ibn Kathīr, Tafsìr al-Qur 'ān al- 'Až̄im, terj. Abdul Ghoffar, Abdurrahim Mu'thi, Abu Ihsan al-Atsari, Vol. 1 (Bogor: Pustaka Imam Asy-Syafi'i, 2004), hlm. 31.

${ }^{38}$ Agus Tricahyo, "Stilistika Al-Qur`an, Memahami Fenomena Kebahasaan al-Qur`an dalam Penciptaan Manusia", Dialogia, 1, (Juni, 2014), hlm. 44. Lihat juga dalam Falah Ibn Mahdi Ibn Sa'id Ibn Mubarok Ali Mahdi, al-Tuhfatu al-Mahdiyah syarh al- 'Aqīdah al-Tadmuriyyah, Vol. 1 (Madinah: Muțāba' al-Jāmi'ah alIslamiyyah, 1991), hlm. 156.
} 
Stilistika Morfologi dalam Ayat-Ayat Penciptaan Manusia Nur Amalina Sholihah

Doi: Doi: doi.org/10.47454/itqan.v3i2.25

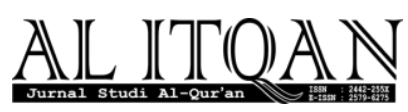

pada bilangan dua. ${ }^{39}$ Sedangkan Allah Subḥānahu wa Ta'ālà mustahil dari sifat itu. Allah Subhānahu wa Ta'ālā sifatnya Esa atau Tunggal. ${ }^{40}$

Damīr naḥnu termasuk ḍamīr jama',yang dapat diucapkan untuk menunjukkan seseorang yang mewakili kelompoknya atau dapat pula disampaikan mewakili seseorang yang agung. Dalam ilmu gramatika Arab, dijelaskan cara mengurutkan peletakan damīr dilihat dari tingkat ma'rifat, damīr mutakallim adalah damīr yang paling ma'rifat. Sehingga dikatakan, bahwa ḍam̄r mutakallim lebih khusus dari pada damīr mukhātab dan ghāib. ${ }^{41}$ Oleh karena itu, jika dibandingkan penggunaan kata kerja خلقنَ Mu'minūn: 12-14 dan al-Hajj: 5 lebih kuat dari pada خلق di QS. al-Naḥl: 4 dan alRaḥman: 14.

Jadi, dilihat dari uraian di atas dapat disimpulkan bahwa penggunaan ḍmīr $n \bar{a}$ dalam lafal (خَلقَنَنَا) khalaqnā dalnā merupakan kata ganti yang sesuai dengan konteksnya. Allah Subḥānahu wa Ta'ālā ingin memberikan penegasan bahwa Dialah yang Maha Agung dan Maha Esa.

\section{Penggunaan Kata بحَعَل , خحلق dan}

Penyebutan redaksi penciptaan manusia dalam QS. al-Mu'minūn: 12-14 dan alHajj: 5, menggunakan beberapa kata kerja yang berbeda, yakni kata جعل ,خلق, dan انشأ Akan tetapi, ketiga kata tersebut sama-sama menggunakan bentuk kata aktif (al-fi'li alma'lūm). Sebelum membahas lebih jauh tentang kata kerja ini, terlebih dahulu akan diuraikan makna dari kata-kata tersebut. Sebab, hal ini akan membantu penelitian lebih lanjut.

Kata خلق yang dari segi bahasa biasa diterjemahkan dengan menjadikan, membuat, atau menciptakan. ${ }^{42}$ Kata ini biasanya digunakan untuk menunjuk penciptaan baik dari bahan yang telah ada sebelumnya maupun belum ada. ${ }^{43}$ Sedangkan kata جعل secara bahasa dapat diartikan (يفعل كذا ${ }^{44}$, yaitu mulai berbuat. Quraish Shihab

\footnotetext{
39 Falaḥ Ibn Mahdi Ibn Sa'id Ibn Mubarok Ali Mahdi, al-Tuḥfatu al-Mahdiyah syarh al-'Aqīdah alTadmuriyyah, Vol. 1, hlm. 156.

${ }^{40}$ al-Qur`an, 112: 1.

${ }^{41}$ Saifudin Masykuri, Kajian dan Analisis Alfiyah, Vol. 1 (Kediri: Santri Salaf Press, 2016), hlm. 81.

${ }^{42}$ Ahman Warsoon Munawwir, Al-Munawwir: Kamus Bahasa Arab-Indonesia(Surabaya: Pustaka Progressif, 1997), hlm. 364.

${ }^{43}$ M. Quraish Shihab, Tafsir al-Misbah, Vol. 8 (Jakarta: Lentera Hati, 2002), hlm. 339. Lihat juga dalam M. Quraish Shihab, Kaidah Tafsir (Tangerang: Lentera Hati, 2013), hlm. 133.

${ }^{44}$ Munawwir, Al-Munawwir, hlm. 196.
} 
menjelaskan bahwa kata ini diartikan "menjadikan". ${ }^{45}$ Sedangkan menjadikan di sini digunakan untuk menunjuk beralihnya sesuatu ke sesuatu yang lain. Hal ini mengandung makna bahwa bahan dari proses tersebut telah ada.

Dari sini, biasanya kata خلق hanya membutuhkan satu objek, berbeda dengan جعل. Di sisi lain, Quraish Syihab memperoleh kesan dari penggunaan al-Qur`an terhadap kata خلق bahwa ia menekankan sisi kehebatan ciptaan Allah Subhānahu wa Ta’ālā, sedang kata جenekankan manfaat yang diperoleh dari sesuatu yang dijadikan itu. Perlu خلق dicatat bahwa bahasa Arab, sebagaimana halnya al-Qur`an biasa menggunakan kata (mencipta) dalam arti جعل (menjadikan) atau sebaliknya. Karena, untuk memahami apa yang dimaksud perlu diperhatikan objeknya. Jika kata جعل hanya menggunakan satu objek, berarti ia bermakna خلق خلق menggunakan dua objek, seperti pada firman-Nya pada ayat 14 di atas (خلقنا النطفة علقة) dan seterusnya, berarti ia bermakna جعل (menjadikan). Namun, karena di sini menggunakan kata خلق, tekanannya di sini adalah pada kehebatan Allah Subhānahu wa Ta'ālā dan ciptan-Nya itu. ${ }^{46}$

Kata انشأ mengandung makna mewujudkan sesuatu serta memelihara dan mendidiknya. Penggunaan kata tersebut dalam menjelaskan proses terakhir dari kejadian manusia mengisyaratkan bahwa proses terakhir itu benar-benar berbeda sepenuhnya dengan sifat, ciri, dan keadaannya dengan apa yang ditemukan dalam proses sebelumnya. Memang, antara nutfah dan `alaqah misal kita anggap berbeda. Namun, perbedaan itu boleh jadi pada warna. Katakanlah nutfah itu cair dan berwarna putih kekuning-kuningan dan `alaqah itu kental berwarna merah, namun keduanya sama, yakni sesuatu yang tidak dapat hidup atau berdiri sendiri, yang berbeda dengan apa yang terjadi sesudah proses ansya'a. $^{47}$

جعل Setelah ditelusuri lafal خلق dalam al-Qur`an setidaknya disebutkan 20 kalii minimal disebutkan 1 kali dan انثأ minimal disebutkan 1 kali. ${ }^{48}$ Allah Subhānahu wa $T a ' a \overline{l a}$ menggunakan bentuk aktif saat menjelaskan tentang penciptaan manusia.

Dalam bahasa Arab, kata kerja atau al-fi'lu dilihat dari segi pelakunya dibagi menjadi dua, yaitu kata kerja aktif (al-fi'lu al-ma'lum) dan kata kerja pasif (al-fi'lu

\footnotetext{
${ }^{45}$ Yang dimaksud menjadikan di sini adalah menjadikan sesuatu dari sesuatu yang lain. M. Quraish Shihab, Kaidah Tafsir, hlm133.

${ }^{46}$ Shihab, Tafsir al-Misbah, Vol. 8, hlm. 339.

${ }^{47}$ Ibid. , Vol. 8, hlm. 339.

${ }^{48}$ Pelacakan ini di dasarkan berdasarkan bahasan proses penciptaan manusia.
} 
Stilistika Morfologi dalam Ayat-Ayat Penciptaan Manusia Nur Amalina Sholihah

Doi: Doi: doi.org/10.47454/itqan.v3i2.25

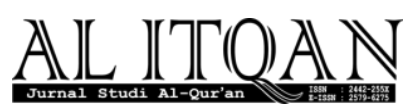

majhul). Kerja aktif adalah apabila pelakunya disebutkan, sedangkan kata kerja pasif adalah apabila pelakunya tidak disebutkan atau dihilangkan. ${ }^{49}$ Musțafa al-Ghulāyayni menyebutkan bahwa dihilangkannya pelaku dari kalimat dikarenakan beberapa faktor ${ }^{50}$, di antaranya tidak perlu diketahui karena sudah diketahui, tidak mungkinnya dijelaskan karena tidak tahu, untuk tujuan menyembunyikan, karena ada ketakutan jika pelaku ditampakkan, untuk menghormati pelaku

Dalam hal ini, ayat-ayat tentang penciptaan manusia sering dibuat dengan menyebutkan pelaku, karena dianggap perlu untuk disebutkan sebagai bentuk dan bukti bahwa Allah Subḥānahu wa Ta'ālā lah yang menciptakan manusia. Allah Subḥānahu wa $T a ' a \overline{l a}$ lah yang menjadikan manusia dengan proses penyempurnaan fisik, peniupan ruh, dan mengatur segala takdirnya. Maksudnya, Allah Subhānahu wa Ta'ālā lah yang mewujudkan sesuatu serta memelihara dan mendidiknya. Argumen ini penulis sampaikan dengan mempertimbangkan penyebutan beberapa faktor yang oleh Musțafa alGhulāyayni di atasdan uraian tentang penggunaan lafal جعلق , جلقأ di das atan.

\section{Penggunaan isim nakirahdan ma'rifat}

Isim nakirah adalah setiap isim yang artinya memuat seluruh afrad (individu/isi) dari jenis tidak tertentu untuk satu tanpa menyertakan yang lain. Secara umum, isim nakirah dapat diartikan sebagai isim yang layak dimasuki ال ma'rifat. ${ }^{51}$ Contoh dari isim nakirah adalah kata رجل (laki-laki). Kata ini mengandung arti satu orang laki-laki namun tidak diketahui siapa laki-laki tersebut. Dengan kata lain, makna رجل bersifat global. Namun, apabila kata tersebut mendapatkan tambahan huruf ال maka makna dari kata tersebut berubah menjadi laki-laki tertentu, bermakna khusus. Dan inilah yang dinamakan isim ma'rifat.

Dalam kajian ayat-ayat proses penciptaan manusia QS. al-Mu'minūn: 12-14 dan al-Hajj: 5, ditemukan beberapa kata dengan asal yang sama, di antaranya kata عَََقًََ, نُطْفَة عِظَامًا ,مُضْغَةً . Akan tetapi, dalam satu konteks yang masih sama, kata tersebut diulang

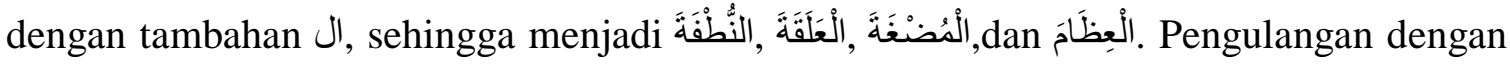
bentuk semacam ini mempunyai rahasia di dalamnya. Berikut uraiannya:

\footnotetext{
${ }^{49}$ Ghalāyaynī, Jāmi’ al-Durūs al- 'Arabiyyah, Vol. 1, hlm. 49

${ }^{50}$ Ibid. , Vol. 1, hlm. 50

${ }^{51}$ Abu An'im, Sang Pangeran Nahwu al-Jurūmiyyah, hlm. 239. Lihat juga dalam Saifudin Masykuri, Kajian dan Analisis Alfiyah, hlm. 65.
} 
Bishrī Musțafa menguraikan bahwa kata nutfatan merupkan isim nakirah, dalam tafsir tersebut dimaknai gandhul dengan ing mani, begitu juga dengan lafal al-nutfata. Pemberian makna di sini juga mempunyai kesamaan dengan lafal 'alaqatan-al-'alaqata, mudghatan-al-muḍhata, dan 'izāaman-al- 'izāma. ${ }^{52}$ Dalam QS. al-Hajj: 5 lafal nutfatan dimaknai dengan saking nutfah (dari nutfah), ${ }^{53}$ sebab kata ini disambung dengan huruf min. Ini ditinjau dari aspek i'rabnya. Begitu juga dengan lafal-lafal yang terdapat dalam QS.al-Mu'minūn: 12-14 di atas. Mengapa dimaknai ing, karena itu menunjukkan dia menempati kedudukan sebagai maf'ul bih.

Terlepas dari aspek i’rabnya, lafa-lafal ini memang tidak mempunyai perubahan dari penyusunan hurufnya secara signifikan. Hanya ada tambahan huruf alif lam didepannya. Dan ini menunjukkan bahwa penambahan huruf tersebut merubah makna menjadi "nutfah itu", dan seterusnya hingga menjadi lebih spesifik. Karena itu merupakan faedah dari isim ma'rifah. Ini menunjukkan bahwa ketika ada isim nakirah pertama dan isim ma'rifat kedua, maka yang kedua sama dengan yang pertama.

\section{Penggunaan gو وَلَََدْ dan nida’ di permulaan ayat}

Dalam proses komunikasi seseorang yang ingin mengartikulasikan ungkapan yang ada dalam hatinya dapat menggunakan beberapa macam ungkapan. Ketika seseorang ingin menyuruh agar orang lain pergi, ia bisa menggunakan satu kata saja “pergi!" atau bisa menggunakan ungkapan yang agak halus "silahkan Anda pergi!" atau bahkan bisa menggunakan bentuk kalimat pertanyaan "Apalagi yang Anda tunggu di sini?”. Ketiga bentuk kalimat tersebut mempunyai maksud yang sama, yakni menyuruh agar orang tersebut pergi. Dari sini, dapat dipahami bahwa untuk menyatakan sebuah perintah tidaklah harus menggunakan bentuk kalimat perintah, tetapi bisa menggunakan bentuk-bentuk yang lain. Demikian juga halnya dengan al-Qur`an, kesan yang ditimbulkan dalam penggunaan lam amr kiranya terasa lebih halus dari pada menggunakan kata kerja perintah. Begitulah gaya al-Qur`an dalam memberikan informasi kepada audien. $^{54}$

Gaya al-Qur`an juga bisa dilihat saat menginformasikan berita tentang proses penciptaan manusia. Dalam hal ini Allah Subḥānahu wa Ta'ālā menggunakan beberapa

\footnotetext{
${ }^{52}$ Bishrī Musțafa, al-Ibrīz, Vol. 18 (Kudus: Maktabah wa Muṭba'ah Menara Qudus, tth), hlm. 1097.

${ }^{53}$ Ibid. , Vol. 17, hlm. 1057.

${ }^{54}$ Agus Tricahyo, hlm. 42.
} 
Stilistika Morfologi dalam Ayat-Ayat Penciptaan Manusia Nur Amalina Sholihah

Doi: Doi: doi.org/10.47454/itqan.v3i2.25

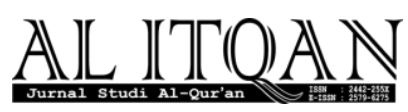

redaksi yang berbeda-beda, di antaranya pertama menggunakan redaksi awal seruan. Contoh ini bisa dilihat dalam QS. Al-Hajj: 5, yang menggunakan redaksi ياأَيْهَا ألنَّاسُ Kedua, menggunakan redaksi penegasan, seperti yang terdapat dalam QS. Al-Hijr: 26, AlInsān: 2, dan Al-Mu'minūn: 12. Ketiga, menggunakan redaksi pertanyaan, seperti pada QS.Al-Mursalāt: 20, Al-Qiyāmah: 37, Yāsīn: 77, dan Al-Kahfi: 37. Dan keempat, menggunakan redaksi pernyataan langsung, seperti pada QS.Al-Rūm: 20, Fātiri :11, Al'Alaq: 2, Al-'An'ām: 2, Al-Naḥl: 4, Al-Ṭāriq: 6, Ghāfir: 67, Șad: 71, Al-Sajdah: [32]: 7, danAl-Raḥmān: 14.

Salah satu redaksi al-Qur`an yang menguatkan kabar tentang proses penciptaan

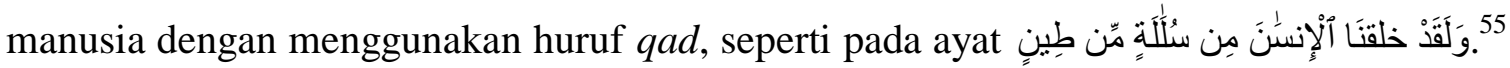
Sebelumnya perlu diketahui bahwa jumlah yang terdapat dalam ayat ini adalah jawabnya qasam yang dibuang. ${ }^{56}$ Huruf waw pada lafal وَكَقَّْ merupakan huruf ataf ${ }^{57}$, karena lafal

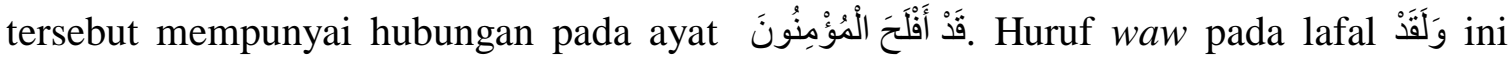
dihukumi istīnăf, sebab dia berada di permulaan kalimat. Maksud dengan permulaan di sini adalah permulaan yang menyimpulkan bahwa Allah Subhānahu wa Ta'ālā itu berbeda dengan mahluk-Nya. Allah Subḥānahu wa Ta'ālā lah Tuhan yang Maha Mulia dan Maha Kuasa. Oleh karena itu, tidak diperbolehkan menyekutukan Allah Subḥānahu wa Ta'ālà dengan selain-Nya, sebab sesungguhnya yang mendidik, membimbing, dan mengarahkan manusia adalah Allah Subḥ̄anahu wa Ta'ālā sendiri. Selain itu, penciptaan manusia dan selainnya ini merupakan bagian dari tanda-tanda akan kekuasaan dan kebesaran nikmat dari Allah Subhānahu wa Ta'āla.$^{58}$ Penguatan kabar ini menggunakan lam qasam dan huruf tahqīq dengan mempertimbangkan pemaparan kaum musyrik yang ingkar terhadap berita ini. ${ }^{59}$

Huruf lam dalam lafal ${ }^{2}$ merupakan jawaban dari qasam yang dibuang. qad yang terdapat dalam لَقَ ini merupakan qad huruf tahqīq. ${ }^{60}$ Dalam kaidah ilmu nahwu, huruf qad biasa digunakan secara bersamaan dengan fi'il madi dan mudari'. Huruf qad ini jika

\footnotetext{
${ }^{55}$ al-Qur`an, 23:12.

${ }^{56}$ Maḥy al-Dīn, I'rāb al-Qur 'ān wa Bayānuh, Vol. 6 (Damaskus: Dār Ibn Kathīr, 1415), hlm. 498.

${ }^{57}$ Huruf atafyaitu huruf yang menyambung pada sebuah objek, tujuan, atau maksud tertentu. Lihat Muhammad Tāhir, al-Taḥrīr wa al-Tanwīr, Vol. 18 (Tunisi: al-Dār al-Tūnisiyah li-Nashr, 1984), hlm. 21

${ }^{58}$ Ibid, Vol. 18, hlm. 21.

${ }^{59}$ Ibid, Vol. 18, hlm. 22.

${ }^{60}$ Maḥy al-Dīn, I'rāb al-Qur 'ān, Vol. 6, hlm. 498.
} 
masuk ke dalam fi 'il maḍi memberikan tiga faedah, yaitu tawaqqu' (mengharap-harap terjadinya pekerjaan $f \bar{a}{ }^{\prime} i l$ ), $\operatorname{tah} q \bar{q} q$ (menguatkan makna $\left.f i{ }^{\prime} i l\right) .{ }^{61}$

Maha benar Allah Subḥ̂̄nahu wa Ta'ālā yang telah mewahyukan ayat ini, sehingga dapat menumbuhkan iman yang kuat. Allah Subhānahu wa Ta'ālā memberi pengingat supaya dia merenung dirinya, betapa asal kejadiannya, dari mana datangnya, betapa dia hidup dan ke mana dia akan kembali. Ini amat perlu diingatkan kepada manusia sebab gelombang hidup kerapkali menyebabkan manusia lupa.

Kemudian, berbeda dengan redaksi yang digunakan dalam ayat QS.al-Hajj: 5. menggunakan nida' (seruan) kepada umat manusia, yang kemudian disusul dengan penyebutan إنْ shartiyyah. Awal ayat ini yang berbunyi يَأَيْهَّا النَّاسن yang mengandung indikasi bahwa ayat ini tergolong ayat makiyyah. ${ }^{62}$ Huruf ya' dan ayyun dalam lafal يَائهَها النَّاسُ merupakan huruf nida’ yang mempunyai faedah untuk memanggil munada yang dekat, jauh, atau yang sedang. ${ }^{63}$

Kandungan ayat ini mencakup akidah atau keimanan. Rasulullah Șalla Allah 'Alaihy wa Sallam menyeru dan menjelaskan kepada kaum kafir Quraish untuk mengimani adanya hari kebangkitan dan penciptaan manusia yang pada saat itu mereka anggap sebagai suatu hal yang dianggap mustahil.

Jadi, dari penjelasan awal ayat di QS. al-Mu'minūn ayat 12 dan al-Hajj ayat 5 dapat disimpulkan bahwa penggunaan lafal ولق merupakan sebuah awal kalimat yang berfungsi mempertegas informasi bahwa manusia tercipta dengan melalui proses yang panjang. Sedangkan kalimat seruan yang digunakan dalam al-Hajj ayat 5 bertujuan untuk menarik perhatian kepada umat manusia akan informasi yang akan disampaikan dalam ayat tersebut.

Dari pemaparan di atas memungkinkan adanya kemungkinan hubungan atau keterkaitan dibalik pemilihan kata-kata pada kedua ayat tersebut. Di antaranya penegasan dan seruan ini dapat menunjukkan tanda-tanda keagungan Allah Subḥānahu wa Ta'ālā. Gambarannya, jika seseorang dipanggil dan diajak bicara dengan redaksi pembiacaraan

\footnotetext{
${ }^{61}$ Abu An'im, Sang Pangeran Nahwu al-Jurümiyyah (Kediri: Mu'jizat Group, tth), hlm. 52.

${ }^{62}$ Dilihat dari aspek waktu turun, ayat atau QS. digolongkan makiyyah apabila ayat atau QS. tersebut turun sebelum Nabi Muhammad Salla Allah 'Alaihy wa Sallam hijrah ke Madinah. Untuk mengetahui ciri-ciri dari

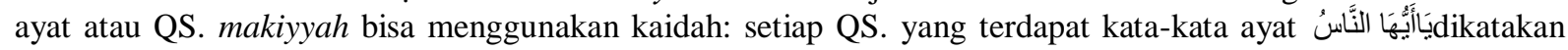
sebagai ayat ayat makiyyah. Lihat di Muhammad 'Abdul Aẓ̄̂m al-Zarqāni, Manāhi al- 'Irfān fì 'Ulümi al-Qur'ān (Beirut: Dār al-Kutb al-'Ilmiyyah, 2010), hlm. 113.

${ }^{63}$ Abu An'im, Sang Pangeran Nahwu al-Jurümiyyah, hlm. 317.
} 
Stilistika Morfologi dalam Ayat-Ayat Penciptaan Manusia Nur Amalina Sholihah

Doi: Doi: doi.org/10.47454/itqan.v3i2.25

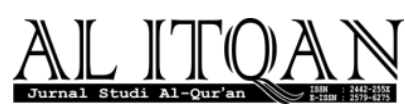

yang tegas, secara tidak langsung dia akan benar-benar berpikir tentang apa yang ada didalamnya.

\section{Penggunaan kata hubung فَ}

Dalam QS. al-Mu'minūn ayat 12-14 dijelaskan tentang tahapan-tahapan penciptaan manusia pada umumnya. Ada dua ațaf atau kata penghubung yang digunakan

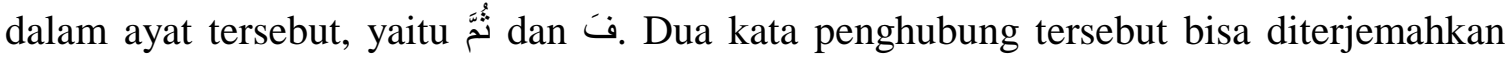
lalu atau maka. Keduanya digunakan untuk menunjuk terjadinya sesuatu setelah sesuatu yang lain, atau adanya peringkat yang berbeda antara apa yang disebut sebelumnya dibandingkan dengan apa yang disebut sesudah salah satu dari kedua kata tersebut.

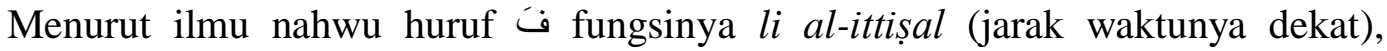
sedangkan fungsinya illi al-infișal (jarak waktunya lama). ${ }^{64}$ Konsep ini bisa digambarkan dengan perkataan, "si A datang kemudian si B" atau "si A datang lalu B." Kalimat pertama mengandung makna bahwa kedatangan si B relatif lama setelah kedatangan si A. Sedang, kalimat yang kedua mengisyaratkan bahwa si B datang tidak lama setelah kedatangan si A.

Dalam QS. al-Mu'minūn 12-14 huruf ف digunakan untuk mengungkapkan perpindahan dari 'alaqah ke mudghah, kemudian mudghah iḍama, kemudian ke laḥma. Jarak waktu antar fase-fase tersebut menurut teori kedokteran tidak terlalu lama dan perubahan bentuknya kurang berarti. Sedangkan perpindahan sari pati tanah ke nutfah, kemudian nutfah ke 'alaqah, dan setelah tulang-belulang beserta daging ke fase tingkat manusia mempunyai tenggang waktu yang cukup lama dan bentuk yang jauh berbeda, maka digunakan kata sambung نُّ

Dalam konteks ayat di atas, sementara ulama memahami penekanan kata thumma dan $f a$ tersebut bukan pada jarak dan waktu, tetapi pada kedudukan dan keajaiban yang demikian tinggi antara yang satu dan yang lain. Ini berarti peralihan dari nutfah ke ‘alaqah serta dari tulang yang terbungkus daging menuju mahluk lain merupakan peralihan yang sangat menakjubkan melebihi ketakjuban yang muncul pada peralihan ‘alaqah ke mudghah atau mudghah ke tulang, demikian juga dari tulang hingga terbungkus daging.

\footnotetext{
${ }^{64}$ Abu An'im, Sang Pangeran Nahwu al-Jurūmiyyah, hlm. 243.
} 
Kemudian, sedikit berbeda dengan penggunaan huruf ațaf yang terdapat dalam QS.al-Hajj: 5, yang hanya menggunakan huruf . Dalam beberapa ayat yang terdapat huruf ataf yang ditampilkan secara berturut-turut ini menjelaskan secara detail terkait perubahan proses penciptaan manusia.

Huruf ataf yang digunakan berturut-turut dalam ayat ini mempunyai sebuah rahasia yang luar biasa. Sesungguhnya Allah Subḥānahu wa Ta'ālā menyebutkan rincian kondisi mahluk dalam perpindahannya. Dia memulai dengan ciptaan yang pertama, yaitu ciptaan Nabi Adam dari tanah liat.Dan ciptaan yang kedua, merupakan ciptaan dari anak cucu Adam. Ini adalah bukti sifat kasih sayang-Nya. Dari sini, dapat dipahami bahwa penggunaan ațaf نُّ didapatkan 2 proses, yaitu Adam dari Tanah dan anak cucu Nabi Adam.

\section{E. Implikasi Stilistika Morfologi terhadap Pemaknaan}

Secara umum tahap penting proses penciptaan manusia yang disebutkan dalam QS. almu'minūn:12-14 dan al-Hajj: 5, dibagi menjadi dua, yaitu proses penyempurnaan fisik atau raga dan proses peniupan ruh. Proses peniupan ruh sendiri merupakan proses yang terjadi setelah bentuk fisik dari janin sudah ada dalam tahap sempurna. Untuk mendapatkan hasil makna yang konkrit tentang penjelasan surahal-Hajj: 5 dan al-Mu'minün: 12-14, maka hal ini akan mengelaborasikan pendapat ulama tafsir tentang ayat tersebut dan ayat-ayat yang berhubungan.

Sehubungan dengan proses penciptaan manusia ini, sebelumnya akandibahas terlebih dahulu sifat yang terkandung dalam ruh. Ruh berasal dari Allah Subhāanahu wa Ta'ālā. Allah Subhạnahu wa Ta'àlā mempunyai sifat suci dan bersih. Oleh karenanya, semua yang berasal dari Allah Subḥānahu wa Ta'ālā pasti suci dan bersih. Jadi ruh yang ditiupkan oleh Allah pada usia kandungan 4 bulan tersebut juga disifati baik. Kumpulan sifat baik yang dibawa oleh ruh inilah yang disebut dengan taqwā.

Berbeda dengan penyempurnaan fisik janin pada rahim ibu selama 4 bulan. Kesempurnaan bentuk fisik ini bersumber dari Allah Subhānahu wa Ta'ālā yang melalui proses ikhtiarnya manusia. Maksudnya, proses penyempurnaan ini tidak langsung dari Allah Subḥānahu wa Ta'àlā. Melainkan manusia di sini juga turut andil dalam prosesnya. Mengapa demikian? Sebab jika ditinjau lebih lanjut, kandungan tidak berkembang dengan baik, jikalau 
Stilistika Morfologi dalam Ayat-Ayat Penciptaan Manusia Nur Amalina Sholihah

Doi: Doi: doi.org/10.47454/itqan.v3i2.25

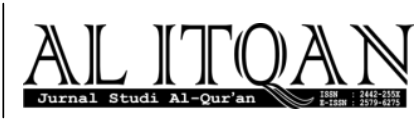

seorang ibu tidak ada asupan yang digunakan untuk menyuplai perkembangan janin itu sendiri.

Sekelompok mufasir berpendapat bahwa yang dimaksud dengan manusia di sini adalah Adam. Mereka mengatakan bahwa air mani lahir dari darah yang terjadi dari makanan, baik yang bersifat hewani maupun yang bersifat nabati. Makanan yang bersifat hewani akan berakhir pada makanan yang bersifat nabati, dan tumbuh-tumbuhan lahir dari saripati tanah dan air. Jadi, pada hakikatnya manusia lahir dari saripati tanah, kemudian saripati itu mengalami perkembangan kpembentukan hingga menjadi air mani. ${ }^{65}$

Kemudian, Allah Subḥānahu wa Ta'ālā jadikan keturunan manusia dari air mani. Air mani tersebut kemudian Dia tempatkan kedalam tempat yang kokoh sejak masa hamil sampai bersalin. Manusia diciptakan dengan dibekali potensi untuk berpikir dan berbicara.Sedangkan mahluk lain tidak. Manusia bisa mendengarkan (kebaikan) sedangkan mahluk lain tidak. Dan mempercayakan batin dan zahirnya. Bahkan setiap anggota dari anggota tubuh lainnya dan setiap bagian dari beberapa bagiannya itu merupakan keajaiban ciptaan yang langka kedudukannya. Tidak sekedar menyifati dalam karakternya, dan tidak sekedar menjelaskan dalam gambaran bentuknya. ${ }^{66}$

Al-Qur`an, dalam berita proses penciptaan manusia mempunyai tahapan-tahapan yang runtut, yaitu dari air mani (sperma) menjadi 'alaqah (segumpal darah). Dari 'alaqah menjadi mudghah (segumpal daging), dari mudghah kemudian dijadikan sedemikian rupa dan bagianbagiannya diuraikan. Bagian yang termasuk dalam pembentukan tulang, dijadikanlah tulang. Dan yang termasuk dalam substansi daging, dijadikanlah daging. Sehingga daging tersebut dijadikan sebagai penutupnya. Dari tahap proses inilah, akhirnya daging ini dijadikan mahluk lain dan ditiupkan ruh di dalamnya. ${ }^{67}$

Dari penyebutan setiap prosesnya di atas, Allah Subḥānahu wa Ta'ālā menggunakan redaksi yang berbeda.Seperti penggunaan taukid, kata hubung, dan kata kerja yang berbeda. Poin ini sudah diterangkan dalam sub bab sebelumnya. Pembahasan tersebut, jika ditarik secara keseluruhan akan mendapatkan implikasi atau pengaruh yang bisa diambil benang merahnya. Yaitu dari permulaan kata yang digunakan pada dua surah di atas, mengandung

\footnotetext{
${ }^{65}$ Musțafa al-Maraghi, Tafsir al-Maraghi, terj. Bahrun Abubakar, Hery Noer Aly, Anshori Umar, Vol. 18, hlm. 12.

${ }^{66}$ Abu al-Qāsim Muhammad Ibn Amr Ibn Ahmad, al-Kashāf 'an Haqāiq Ghawāẹ al-Tanzīl Vol. 3 (Beirut: Dār al-Kitāb al-'Arabī, 1985), hlm. 178.

${ }^{67}$ Mustafa al-Maraghi, Tafsir al-Maraghi, Vol. 18, hlm. 13.
} 
pemahaman bahwa Allah Subḥānahu wa Ta'ālā mecoba memberikan kabar dengan menyeru dan mempertegas akan keagungan Allah Subhānahu wa Ta'ālā kepada umat manusia melalui ciptaan-Nya. Seruan ini bersifat global. Ini bisa dilihat dari redaksi dan pilihan kata yang digunakan dalam QS.al-Hajj: 5, yaitu penggunaan huruf nida', kata kerja khalaqa, dan kata hubung thumma.

Berbeda dengan QS. al-Mu'minūn: 12-14. Redaksi dan pilihan kata yang digunakan pada permulaan ayat dengan huruf qad, kata kerja menggunakan khalaqa dan ja'ala, sedangkan kata hubung menggunakan thumma dan $f a$ dalam perpindahan prosesnya.

Sebelumnya telah dibahas bahwa kata khalaqa lebih menekankan sisi kehebatan ciptaan Allah Subḥānahu wa Ta'ālā dan kata ja'ala lebih menekankan pada manfaat yang diperoleh dari sesuatu yang dijadikan. ${ }^{68}$ Penggunaan kata ja`aladengan hanya satu objek berarti khalaqa/mencipta dan bila kata khalaqa menggunakan dua objek, maka ia berarti menjadikan.

Berangkat dari argumen di atas, dapat disimpulkan bahwa lafal khalaqa pada ayat menunjukkan makna menjadikan atau ja'ala. Sebab kata khalaqa di sini menggunakan bahan yang sebelumnya sudah ada. Dan mempunyai

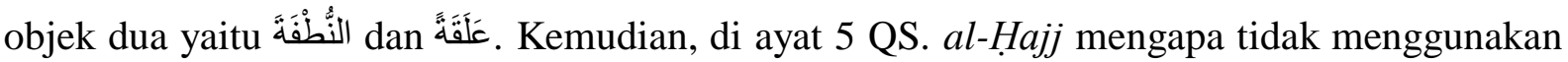
lafal جعل, sebab melihat dari munasabah ayat, ayat ini ditujukan untuk membantah orangorang yang tidak iman adanya hari kebangkitan. Oleh karena itu, tepat jika pilihan kata menggunakan lafal خلق. Mengingat kata ini mempunyai faidah mengagungkan.

Berkaitan dengan kata penghubung. Kata penghubung thumma dan fa dalam QS. alMu'minūn: 12-14 menunjukkan pemahaman bahwa ayat ini sedang berbicara tentang penegasan akan proses penciptaan manusia. Oleh karena itu, dalam ayat ini dijelaskan secara detail dengan menggunakan dua kata hubung yang berbeda. ${ }^{*}$ menunjukkan faidah bahwa proses itu membutuhkan waktu yang lama, sedangkan ف menunjukkan faidah bahwa proses itu membutuhkan waktu yang singkat.

penggunaan kata hubung dalam QS. al-Hajj: 5 hanya menggunakan huruf ث, memberikan kesimpulan bahwa ini untuk mempermudah pemahaman si kaum yang tidak percaya akan hari kebangkitan. Oleh karena itu, kiranya dalam konteks ini tidak perlu menyebutkan kalimat yang sulit dipahami, cukup menyebutkan rangkaian kalimat yang

\footnotetext{
${ }^{68}$ M. Quraish Shihab, Tafsir al-Misbah, Vol. 8, hlm. 339.
} 
Stilistika Morfologi dalam Ayat-Ayat Penciptaan Manusia Nur Amalina Sholihah

Doi: Doi: doi.org/10.47454/itqan.v3i2.25

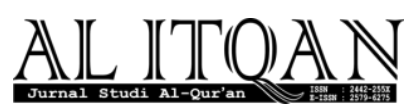

sederhana. Sehingga dengan redaksi yang sederhana itu, diharapkan cepat mengantarkan pada sebuah pemahaman. Demikianlah jika huruf thumma dipilih dalam redaksi ini. Sebab, thumma (kemudian) dalam kandungan artinya menunjukkan sebuah proses yang saling berkesinambungan dan dilakukan secara tertib berurutan. Ini menurut konsep yang biasa digunakan. $^{69}$

\section{F. Penutup}

Dari analisis penulis terkait kajian morfologi ayat proses penciptaan manusia, dapat disimpulkan bahwa redaksi yang digunakan oleh al-Qur`an dalam surah al-Mu'minūn ayat 12-14 dan surah al-Hajj ayat 5 ada beberapa perbedaan dalam hal struktur kata dan pilihan kata yang digunakan. Di antaranya, perbedaan penggunaan redaksi yang terdapat pada permulaan ayatnya, perbedaan struktur kalimat dalam mengabarkan tahapan penciptaan manusia, dan perbedaan penggunaan kata hubung. Perbedaan ini dilatarbelakangi oleh adanya perbedaan keadaan antara kedua ayat tersebut. QS. al-Mu'minūn:12-14 menunjukkan penegasan dan penguatan atas keagungan pemberian Allah Subhānahu wa Ta'ālā, setelah menceritakan keadaan orang-orang yang berbahagia dan beruntung. Sedangkan dalam QS. alHajj: 5 menunjukkan adanya kelompok manusia yang tidak percaya dan membantah tentang kuasa Allah Subhānahu wa Ta'ālā untuk membangkitkan manusia setelah kematian. Pilihan kata yang digunakan setiap ayat tersebut dinilai tepat sesuai dengan keadaan.

Perbedaan redaksi pada ayat-ayat proses penciptaan manusia tidak membawa penyimpangan terhadap makna yang ingin disampaikan oleh al-Qur`an. Justru hal tersebut membawa pengaruh terhadap pemaknaan, yaitu setiap ayat dapat memberikan penjelasan dan penguatan antara satu dengan lainnya. Perbedaan ini menunjukkan sisi kemu'jizatan alQur`an dan tingginya tingkat sastra al-Qur`an itu sendiri.

\section{DAFTAR PUSTAKA}

Ahmad, Abu al-Qāsim Muhammad bin Amr bin. al-Kashāf 'an Haqāiq Ghawāọ al-Tanzīl. Beirut: Dār al-Kitāb al-‘Arab̄̄, 1985.

An’im, Abu. Sang Pangeran Nahwu al-Jurūmiyyah. Kediri: Mu'jizat Group, tth.

Daud, Muhammad.al-'Arabiyah wa 'Ilm al-Lughah al-Hadis. Kairo: Dār al-Gharīb, 2001.

\footnotetext{
${ }^{69}$ Mayl Badi' Ya'qub, Mausū'ah al-nahwu wa al-Ṣarf wa al-I'rab, (Rembang: al-Maktabah al-Anwāriyah, th), hlm. 286.
} 
Dīn (al), Maḥya. I'rāb al-Qur 'ān wa Bayānihi. Damaskus: Dār Ibn Kathīr, 1415.

Ghalāyayn̄̄, Mușțafa bin Muhammad Sālim. Jāmi' al-Durūs al-'Arabiyyah. Beirut: alMaktabah al-Ash'ariyyah, 1993.

HakimM. Aunul. “Stilistika Morfologi Al-Quran Juz 30”. Lingua. 5. Juni 2010.

Kathīr, Abū al-Fidā' Ismā'il bin Umar bin. Tafsīr al-Qur 'ān al-'Az̄ìm. terj. Abdul Ghoffar, Abdurrahim Mu’thi, Abu Ihsan al-Atsari. Bogor: Pustaka Imam Asy-Syafi’i, 2004.

Lajnah Pentashihan Mushaf al-Qur`an. Penciptaan Manusia: Dalam Perspektif al-Qur`an dan Sains. Jakarta: Lajnah Pentashihan Mushaf al-Qur`an, 2010.

Mahdi, Falaḥ bin Mahdi bin Sa'id bin Mubarok Ali. al-Tuhfatu al-Mahdiyah syarh al- 'Aqīdah al-Tadmuriyyah. Madinah: Muțāba' al-Jāmi’ah al-Islamiyyah, 1991.

Maraghi (al), Musțafa.Tafsir al-Maraghi. terj. Bahrun Abubakar. Hery Noer Aly, Anshori Umar. Juz 18.

Masykuri, Saifudin. Kajian dan Analisis Alfiyah. Kediri: Santri Salaf Press, 2016.

Munawwir, Ahman Warsoon. Al-Munawwir: Kamus Bahasa Arab-Indonesia. Surabaya: Pustaka Progressif, 1997.

Mursalim. "Gaya Bahasa Pengulangan Kisah Nabi Musa as dalam Al-Qur'an: Suatu Kajian Stilistika". Lentera. vol 1. no 1 Juni 2017.

Musțafa, Bishrī. al-Ibrīz. Kudus: Maktabah wa Muṭba’ah Menara Qudus, tth.

Muzakki, Akhmad.Stilistika al-Qur`an: Memahami Karakteristik Bahasa Ayat-Ayat Eskatologi. Malang: 2015, UIN-Maliki Press..

Purnanto, Dwi.“Kajian Morfologi Derivasional dan Infleksional dalam Bahasa Indonesia”. Kajian Linguistik dan Sastra. 18. 2006.

Qalyubi, Syihabuddin. 'Ilm al-Uslūb: Stilistika Bahasa dan Sastra Arab. Yogyakarta: Karya Media, 2013.

Stilistika al-Qur`an : Makna di Balik Kisah Ibrahim. Yogyakarta: Lkis, 2008.

. Stilistika Al-Qur`an. Yogyakarta: LKIS, 2008. 
Stilistika Morfologi dalam Ayat-Ayat Penciptaan Manusia Nur Amalina Sholihah

Doi: Doi: doi.org/10.47454/itqan.v3i2.25

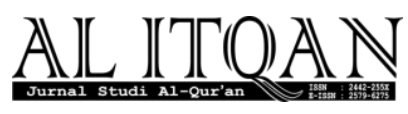

Qațtan (al), Manna'. Mabāhith fi 'ulūm al-Qur'ān. terj. Umar Mujtahid. Jakarta: Ummul Qurra', 2016.

Shihab, M. Quraish. Kaidah Tafsir. Tangerang: Lentera Hati, 2013.

Tafsir al-Misbah. Jakarta: Lentera Hati, 2002.

Ṭāhir, Muhammad. al-Taḥrīr wa al-Tanwīr. Tunisi: al-Dār al-Tūnisiyah li-Nashr, 1984.

Tim penyusun Kamus Pusat Bahasa. Kamus Bahasa Indonesia. Jakarta: Departemen Pendidikan Nasional, 2008.

Tricahyo, Agus. "Stilistika Al-Qur`an, Memahami Fenomena Kebahasaan al-Qur`an dalam Penciptaan Manusia”. Dialogia. 1. Juni, 2014.

Ya'qub, Mayl Badi'. Mausū'ah al-nahwu wa al-Ṣarf wa al-I'rab. Rembang: al-Maktabah alAnwāriyah, tth.

Zarqāni (al), Muhammad 'Abdul Aẓīm. Manāhi al-'Irfān fì 'Ulūmi al-Qur'ān. Beirut: Dār alKutb al-'Ilmiyyah, 2010. 
